\title{
$30(2) \cdot 2016$
}

\author{
JACEK SOŁTYS
}

Gdansk University of Technology, Poland

SŁAWOMIR DOROCKI

Pedagogical University of Cracow, Poland

\section{Non-metropolitan Industrial NUTS 3 Sub-regions in the European Union - Identification and Typology}

\begin{abstract}
A common phenomenon of development is the big difference in its levels, especially between metropolitan and non-metropolitan areas. Non-metropolitan areas are also very different. In some of them, industry plays a big role. European Union's NUTS 3 non-metropolitan low developed sub-regions, whose gross domestic product per capita in 2011 was below $75 \%$ of the EU average, were the subject of research. It is based on the data and Principal Component Analysis used for the typology of 319 sub-regions prepared in 2014. The purposes of the research presented were to identify industrial sub-regions among aforementioned sub-regions, to investigate their diversity and to recognize more detailed sub-regions with the most developed industry. There was also a methodological purpose: to verify a concept for taking into account the weight of principal component in grouping sub-regions into types. As many as 53 sub-regions, in which the rate of gross value added in industry (in \%) is 3 times bigger than average in the whole set of the sub-regions examined (that is more than 35\%) were defined as industrial. Typology for these sub-regions was made by the cluster analysis using hierarchical method and grouping sub-regions into four types. More detailed characteristics of some sub-regions is the last part of this work.
\end{abstract}

Keywords: European Union; industry; non-metropolitan sub-regions; peripheral areas; typology

Received: 18 January 2016

Accepted: 24 May 2016

\section{Suggested citation:}

Sołtys, J., Dorocki, S. (2016). Non-metropolitan Industrial NUTS 3 Sub-regions in the European Union Identification and Typology. Prace Komisji Geografii Przemysłu Polskiego Towarzystwa Geograficznego [Studies of the Industrial Geography Commision of the Polish Geographical Society], 30(2), 55-71.

\section{INTRODUCTION}

Large differences in levels of development are a common phenomenon, especially between metropolitan and non-metropolitan areas, called peripheral. The term "peripheral" refers to the theory of cores and peripheries of J. Friedman, relative to the theory of growth poles. The cores are territorial social subsystems with a high ability to generate innovation, the peripheries are all regions outside the cores (Domański, 2005, 2008; Dorocki, 2012).

There are differences between sub-regions of the capitals of regions and other sub-regions. For this reason sub-regions at NUTS 3 level were the objects of the 
research, despite the fact that there is less data for this level than for regions at NUTS 2 level. NUTS 2 is considered too big to capture specific territories, among other economic differentiations (Bauer, 2010). The second reason of the choice of NUTS 3 level concerns delimitation. In this article the non-metro regions are examined according to Eurostat (Typology, 2012), where delimitation was in NUTS 3 level.

Non-metropolitan sub-regions are also very diverse. Two typologies were applied as a first step to recognize this diversity (Sołtys, 2014, 2015). One of the biggest problems of numerous non-metropolitan sub-regions is a low level of development (Dorocki, 2010). For this reason, the above-mentioned typologies were made for 319 sub-regions, in which GDP per capita is below 75\% of the EU average. Sub-regions in 19 countries fulfill those criteria. There are no such sub-regions in: Austria, Cyprus, Denmark, Finland, France, Ireland, Luxembourg, Netherlands and Sweden.

According to the economic base theory, exogenous activities are the engine of development (Gałązka, 2011). Industry is such an exogenous activity, especially in the areas, where there is a lack of value for tourism and health resorts. The above-mentioned typologies show that in the European Union there are non-metropolitan low developed sub-regions with well-developed industry (Dorocki, 2008). They do not create one type (Sołtys, 2004, 2015). It inspired the authors to perform more detailed study concerning only industrial sub-regions.

The purposes of the work was to identify non-metropolitan low developed industrial NUTS 3 sub-regions in the European Union, to investigate the diversity of these sub-regions and to recognize more detailed sub-regions with the most developed industry. There was also a methodological purpose: to create and to verify a concept for taking into account various weight of principal component in grouping sub-regions into types.

The list of variables, the data and Principal Component Analysis (PCA) from above-mentioned typologies were used as a basis for the research (Gorzelak, 1979). The use of the results of PCA prepared for a large set of sub-regions is considered to be better than the preparation of a new PCA for a small set of data. The data were sourced from Eurostat, which determined the set of variables. Most of the data used in the typologies concern 2011. The data from the Eurostat also pre-determined the years for measurement of dynamics. For some countries, these data only included the following periods: 2006-2012, 2007-2010, 2007-2011 or 2007-2012. The lack of some demographic data for those years causes that typologies excluded some sub-regions in Germany (DED2F -Sächsische Schweiz-Osterzgebirge, DED42 - Erzgebirgskreis) and Italy (ITF46 - Foggia, ITF48 - Andria-Trani) (Sołtys, 2015).

Industrial sub-regions are defined as sub-regions in which a rate of gross value added in industry (in \%) is three times bigger than average in the whole set of non-metropolitan low developed sub-regions, that is more than $34.8 \%$. For the typology the cluster analysis using hierarchical agglomeration method with creating dendrite was applied.

More detailed characteristics of some sub-regions are in the last part of this work. 


\section{VARIABLES CHARACTERIZING SUB-REGIONS}

As many as 24 input variables were selected to characterize each sub-region. They cover the following aspects important for the regional development:

1. level of economic and socio-economic development,

2. dynamics of economic and socio-economic development,

3. demographic features,

4. structure of economy,

5. intensity of use of space.

The level of economic development was calculated as gross domestic product (GDP) per capita, which is presented as a percentage of the total for EU28. The level of socio-economic development was measured by the employment rate per 1,000 persons of working age, which is 15-64 years old (EMP).

Dynamics of economic and socio-economic growth were measured by the following indicators:

- growth rate of employment for the period 2006-2012 (EMD);

- growth rate of gross value added (GVA) at basic prices for the period 2007-2011; in:

- agriculture, forestry and fishing (VAD),

- industry (VID),

- construction (VCD),

- services (VSD);

- net migration rates for $2007-2010$ per 1,000 population, as the average for 2007 2011 (MIGR);

- dynamics of total population change for the period 2007-2012 per 1,000 inhabitants, as the average for 2007-2012 (POPD).

Net migration rates and dynamics of total population change may be to some extent treated as equivalents of "Quality of Life" because these indicators are in some cases correlated with "Quality of Life" and there is a lack of quantitative indicators for this quality.

Two demographic indicators concerning the age structure were also used:

- age dependence ratio - people of non-working age (younger than 15 or older than 64) per 1,000 working-age population (AGE1),

- ratio of people of post-working age (older than 64) - to the people of pre-working age (younger than 15) (AGE2).

The structure of economy was measured according to the following NACE (The acronym for Nomenclature Statistique des Activités Économiques dans la Communauté Européenne- statistical classification of economic activities in the European Community (Eurostat 2008)) indicators:

- employment rate per 1,000 persons of working age (15-64); in: agriculture, forestry and fishing (EMAP),

industry (EMIP), construction (EMCP), services (EMSP); 
- gross value added (GVA) per 1,000 persons of working age (15-64), in: agriculture, forestry and fishing (VAP), industry (VIP), construction (VCP), services (VSP);

- gross value added - rate in \%, in:

agriculture, forestry and fishing (VA\%), industry (VI\%), construction (VC\%), services (VS\%).

Intensity of space used was measured by population density - persons per square meter (DENS).

A standardization of variables listed above was prepared. Then, the correlations between these variables were calculated using Pearson's product-moment correlation coefficient. The resulting correlations were not high: only 19 correlation coefficients are higher than 0.50 . The highest correlation coefficients appear between: GDP and gross value added per 1,000 habitants of working age in services (0.94), gross value added (in $\%$ ) in industry and in service (negative coefficients -0.92), employees in industry per 1,000 habitants of working age and gross value added (in \%) in industry (0.84), gross value added in services per 1,000 habitants of working age and gross value added (in $\%$ ) in services (0.83), GDP and gross value added in construction per 1000 habitants in working age (0.76), GDP and employees in services per 1000 habitants in working age $(0.70)$. When PCA is used, the use of variables that are correlated is allowed.

\section{IDENTIFICATION OF NON-METROPOLITAN INDUSTRIAL SUB-REGIONS IN THE EUROPEAN UNION}

Two problems occur in the selection criteria for the identification of industrial sub-regions: selecting the variables and establishing the limit of value of a selected variable. Two indicators from 24 variables listed above are appropriate for the identification of industrial sub-regions: gross value added (in \%) in industry and employment rate per 1,000 persons of working age in industry. An indicator concerned gross value added was considered to be better due to the nature of modern industry: the increasing automation causing a decline in employment and increase in value. Another reason why the indicator concerned employment was considered to be worse is the big employment in the agriculture in some regions, which distorts the result reducing the role of the industry. For example, in ciechanowsko-płocki sub-region, in which refinery and petrochemical industry is highly developed, employment rate per 1,000 persons of working age in the industry achieves only 108 (1.6 times the average for the whole set of 319 sub-regions). An analogous indicator for agriculture is 130. Gross value added in industry in this sub-region achieves 41.7 (3.1 times the average for the whole set of 319 sub-regions). The third indicator concerned industry - gross value added per 1,000 persons of working age (in \%) - was considered appropriate for identification of sub-regions with highly developed industry. It is not the same as industrial sub-regions, 
because it is possible that in a region with a highly developed industry services are more developed and naming such a region as industrial would be inappropriate. The limit of value of a selected variable as an criterion for the identification of industrial sub-regions arbitrarily assumed as 3-times the average of this indicator for the whole set of 319 non-metropolitan low developed sub-regions, that is $34.8 \%$.

There are 53 sub-regions which fulfill the above-mentioned criterion. They are shown in Figure 3 and listed in one of the further chapters. They belong to 10 countries. Among them there are 3 sub-regions in Portugal. Other sub-regions are in post-socialist countries. There are also 6 industrial sub-regions in Czech Republic, 7 in Bulgaria, 6 in Hungary, 5 in Poland and Slovenia, 2 in Slovakia, 1 in Latvia and Estonia. Lack of countries of the "old" European Union except Portugal indicates that in the missing countries the services are better developed than in the 53 sub-regions identified as industrial.

Tab. 1. Characteristics of non-metropolitan industrial sub-regions in comparison to all 319 non-metropolitan sub-regions

\begin{tabular}{|c|c|c|c|c|c|c|}
\hline \multirow[t]{2}{*}{ Variables } & \multicolumn{3}{|c|}{53 industrial sub-regions } & \multicolumn{3}{|c|}{$\begin{array}{l}319 \text { non-metropolitan sub- } \\
\text { regions }\end{array}$} \\
\hline & $\min$ & $\max$ & range & $\min$ & $\max$ & range \\
\hline $\begin{array}{l}\text { Gross domestic product per capita as \% of } \\
\text { EU28 average }\end{array}$ & 11.0 & 71.0 & 60.0 & 10.0 & 74.0 & 64.0 \\
\hline $\begin{array}{l}\text { Gross value added \% in: } \\
\text { agriculture }\end{array}$ & 1.0 & 17.9 & 16.9 & 0.1 & 27.4 & 27.3 \\
\hline industry & 34.8 & 63.8 & 29.0 & 1.3 & 63.8 & 62.5 \\
\hline construction & 0.7 & 11.3 & 10.6 & 0.7 & 15.9 & 15.2 \\
\hline services & 29.6 & 58.4 & 28.8 & 29.6 & 91.5 & 61.9 \\
\hline $\begin{array}{l}\text { Employees per } 1000 \text { inhabitants in working } \\
\text { age: } \\
\quad \text { total }\end{array}$ & 381 & 784 & 403 & 343 & 1036 & 693 \\
\hline in agriculture & 6 & 362 & 356 & 1 & 480 & 479 \\
\hline in industry & 98 & 307 & 209 & 20 & 307 & 287 \\
\hline in construction & 13 & 75 & 62 & 12 & 98 & 86 \\
\hline in services & 141 & 363 & 222 & 141 & 620 & 479 \\
\hline $\begin{array}{l}\text { Gross value added per } 1000 \text { inhabitants in } \\
\text { working age in: } \\
\text { agriculture }\end{array}$ & 0.2 & 1.4 & 1.2 & 0 & 3.4 & 3.4 \\
\hline industry & 1.3 & 13.7 & 12.4 & 0.3 & 13.7 & 13.4 \\
\hline Population density & 34.3 & 411 & 376.7 & 7.1 & 2135 & 2128 \\
\hline $\begin{array}{l}\text { Net migration in } 2007-2010 \text { per } 1000 \\
\text { inhabitants }\end{array}$ & -10.6 & 6.9 & 17.5 & -14.2 & 18.8 & 33.0 \\
\hline $\begin{array}{l}\text { Growth rate of: } \\
\text { population }\end{array}$ & 85.8 & 103.5 & 17.7 & 82.4 & 119.3 & 36.9 \\
\hline employment in 2006-2012 & 71.7 & 120 & 48.3 & 68.5 & 163.4 & 94.9 \\
\hline gross value added in services & 73.7 & 137.5 & 63.8 & 68.5 & 163.4 & 94.9 \\
\hline
\end{tabular}

Source: own elaboration based on Eurostat 
Industrial sub-regions are very diverse although, of course, less diverse than the entire set of 319 sub-regions (Table 1). The most similar is the diversity of both sets of sub-regions in terms of indicators: of gross domestic product per capita. The highest diversification in both sets of sub-regions concerns agriculture: employees per 1000 inhabitants in working age in agriculture and gross value added in agriculture in \%. High diversification in industrial sub-regions concerns also indicators: gross domestic product per capita, gross value added in construction in \%, gross value added per 1000 inhabitants in working age in agriculture and in industry, population density. In 43\% of industrial sub-regions the net migration is positive; only in $26 \%$ of industrial sub-regions there was growth of population.

\section{PROCEDURE OF TYPOLOGY}

In the Principal Components Analysis (PCA) a large number of related variables are transformed to a smaller set of uncorrelated variables (Jackson, 1991). "The main idea of PCA is to reduce the dimensionality of a data set [...], while retaining as much as possible of the variation present in the data set" (Lolliffe, 2002: 1). The theoretical basis for principal component analysis is available in the following papers: Morrison (1967), Chojnicki and Czyż (1978), Maćkiewicz, Ratajczak (1993), Parysek and Ratajczak (2002), Nowak (2012). PCA is used, while applying orthogonal Varimax rotation to maximize the factor differences. After this rotation, each original variable tends to be associated with one (or a small number) of components, and each component represents only a small number of variables. Each component has a small number of large loadings and a large number of zero (or small) loadings (Abdi, Williams 2010). Only those components in which eigenvalue is greater than 1 should be taken for rotation.

After carrying out PCA for 319 non-metropolitan low developed sub-regions in the European Union, the eigenvalues greater than 1 appeared for 7 principal components, so only those 7 components were used in rotation and further procedure (Sołtys, 2015). These 7 rotated components, hereafter referred to as RC1, RC2, RC3, etc., explain $78 \%$ of the total variance of all variables. Table 2 presents a matrix of the loadings of 7 rotated principal components.

The component RC1 correlates mainly with GDP, and negatively with two variables concerning agriculture, forestry and fishing. As a result, RC1 can be termed economic development. RC2 has very high negative correlations with variables concerning development of industry and positive correlation with the variable concerning development of services. This component can be termed service/industry. RC3 has a high correlation (0.93) with the number of employees per 1,000 inhabitants of working age, and thus, it can be termed employment. RC4 correlates mainly with variables concerning the development of construction, so it can be termed development of construction. RC5 concerns variables of demography, so it can be termed demography. RC6 positively correlates $(0.78)$ with the variable gross value added in agriculture, forestry and fishing per 1,000 habitants of working age. Negative correlation is with density $(-0.69)$. As a result, this component can be termed development of agriculture. RC7 correlates 
Tab. 2. Principal components greater than 0.3 after Varimax rotation.

\begin{tabular}{|l|c|c|c|c|c|c|c|}
\hline \multicolumn{1}{|c|}{ Variables } & RC1 & RC2 & RC3 & RC4 & RC5 & RC6 & RC7 \\
\hline GDP & 0.79 & 0.38 & & & & & \\
\hline EMP & & & 0.93 & & & & \\
\hline EMD & & & & & 0.58 & & 0.34 \\
\hline VAD & -0.41 & & & & & & \\
\hline VID & -0.37 & & & & & & 0.44 \\
\hline VCD & & & & 0.62 & & & 0.55 \\
\hline VSD & & & & & & & 0.86 \\
\hline MIGR & 0.38 & & & & 0.65 & & \\
\hline POPD & 0.46 & & & & 0.69 & & \\
\hline AGE1 & & 0.59 & 0.45 & & -0.38 & & \\
\hline AGE2 & & 0.37 & 0.36 & & -0.62 & & \\
\hline EMAP & -0.79 & & 0.36 & & & & \\
\hline EMIP & & -0.89 & & & & & \\
\hline EMCP & 0.38 & & 0.57 & 0.48 & & & \\
\hline EMSP & 0.56 & 0.37 & 0.51 & & & & \\
\hline VAP & & 0.36 & & & & 0.78 & \\
\hline VIP & 0.62 & -0.57 & 0.31 & & & & \\
\hline VCP & 0.58 & & & 0.66 & & & \\
\hline VSP & 0.68 & 0.63 & & & & & \\
\hline VA\% & -0.84 & & & & & 0.37 & \\
\hline VI\% & & -0.97 & & & & & \\
\hline VC\% & & & & 0.93 & & & \\
\hline VS\% & 6.62 & 3.95 & 2.38 & 1.73 & 1.53 & 1.35 & 1.10 \\
\hline DENS & & 44.1 & 54.0 & 61.2 & 67.6 & 73.2 & 77.8 \\
\hline Eigenvalue & & & & & & \\
\hline Cumulative proportion of variance & & & & & & -0.69 & \\
\hline SOined in\% & & & & & & \\
\hline
\end{tabular}

Source: Sołtys (2015)

with the dynamics of gross value added by NACE. The highest correlation concerns the dynamics of services (0.86), with lower correlations for construction (0.55), industry (0.44) and the dynamics of the number of employees (0.34). This component can be termed dynamics of development, mainly of ser-vices (Sołtys, 2015).

Cluster analysis was applied for the typology. It is the preferred generic term for procedures which seek to uncover groups of data (Everitt et al., 2011). In typology based on PCA and cluster analysis describing among others by Shepherd (2009) there are two stages after using PCA:

- Scoring sub-regions on the dimensions of variation (by a matrix of transformed data).

- Grouping sub-regions. 
Fig. 1. Dendrogram for clustering sub-regions by Ward's method

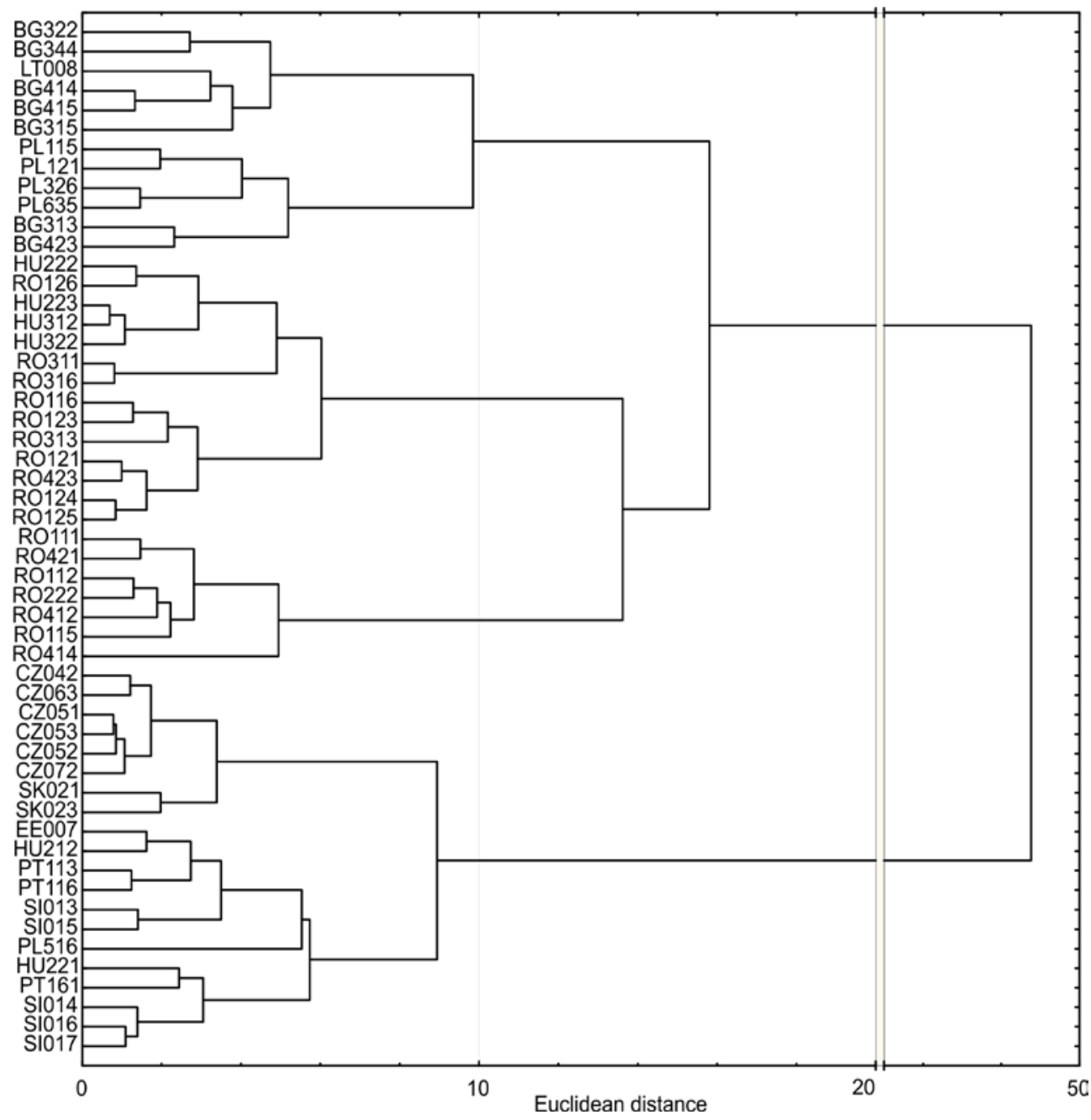

Source: own elaboration based on Eurostat

After using PCA the typology was based on the transformed data matrix for 7 rotated principal components. The final stage in the process involved clustering of the sub-regions according to their scores (numerical "distances") in the 7 dimensions in the transformed data. The hierarchical agglomeration Ward's method with creating dendrite was applied for clustering.

Each component explains a different proportion of variance. It caused a concept for taking into account their eigenvalues for multiplying the data in the columns. But after this multiplying only component 1 creates main three types. The authors tested other variants, taking into account various parts $(50 \%, 33 \%, 25 \%)$ of eigenvalues for modification data matrix, grouping sub-regions and analysing dendrogram. The variant 
with $25 \%$ which grouped the date into 4 types was chosen, because it seemed to be clear (Fig. 1) and not only 1 component took part in grouping. Data matrix was transformed according to the formula:

$$
\text { aij' }^{\prime}=0,25(\lambda j-1) \text { aij }+1
$$

where:

aij is an element of a transformed data matrix for sub-region i and eigenvalue, aij' is an element of a modification data matrix for sub-region i and component $j$, $\lambda \mathrm{j}$ is eigenvalue of a component $\mathrm{j}$.

The components in new transformed matrix in tables are referred to as MC1, MC2, MC3 etc.

\section{TYPES AND ITS DESCRIPTION}

The types were numbered according to the average values of the component MC1 (Table 3) due to their big role in clustering. The differences between the sub-regions are small in terms of the component 2 and 6, a bit more - in terms of another components, in particular 7. The distances in the dendrogram (Fig. 1) show that the types 2, 3 , and 4 are more similar to each other than to the type 1. Each of the four types was characterized by: average (see Fig. 2), minimum and maximum of the principal components (see Table 3).

Fig. 2. Types of cluster profiles using the average values of the modified principal components



Source: own elaboration based on Eurostat

When a standard deviation is smaller, cluster has the lowest dispersion in terms of the given factor. The data in Table 2 shows that clusters are spread. It causes some difficulty in type description, which differs typologies from classification. In classification 
objects according to each component would be split into classes. Some classes would contain no members (Banning 2000). In the presented case, preparing classes for 7 components would be too much. As an alternative, a classification or typology for the two principal components could be considered, but in these cases $56 \%$ of the variation would not be taken into account. The disadvantages of the obtained typology relate to large ranges of values of components in one type and similar values of one component in more than one type. For these reasons, types must be characterized by several components at once, not by single components and by all measures at once (average, maximum and minimum) and even by more detailed characteristic of specific values in every type. This situation results in difficulties in interpretation of obtained types. It can be supposed that a large number of variables used in the typology, low correlated, resulting in a large number of principal components, has an impact on the results of the typology and the above-mentioned interpretational difficulties.

The resulting clusters include between 7 and 19 sub-regions. The characteristics of the types by input variable raw values is more readable for types interpretation (Table 4).

The simplified characteristics of types are as follows:

Type 1 - the most developed sub-regions among sub-regions examined (GDP $32-71 \%$ of EU, aver-age 52\%). Growth rate of employment in 2006-2012 average for the type was 98 . Only in $37 \%$ of sub-regions the GVA has increased. Growth rate of gross value added in services in 2007-2011 (high correlated with the 7. component) was positive in almost all sub-regions, except 2 (average 114). In almost all sub-regions (except 3) net migration is positive and in most sub-regions (58\%) the population has increased. In 74\% sub-regions population density is above 100.

Type 2 - medium and less developed sub-regions (average of GDP 25\% of EU. The lowest level of construction development. Growth rate of employment in 2006-2012 was various (71.7-120.0, average for the type -95). Growth rate of gross value added in services in 2007-2011 was similar to the type 1 - positive in almost all sub-regions (except 1), average was 113.). In almost all sub-regions (except 3 ) the net migration is negative and the population has decreased.

Type 3 - medium and less developed sub-regions, in terms of component 2 . and GDP similar to the type 2 (average of GDP $23.5 \%$ of EU). In $71 \%$ sub-regions net migration is negative, in all sub-regions the population has decreased. Growth rate of employment in 2006-2012 average for this type was the lowest among sub-regions examined (91). In all sub-regions employment has been decreased. Growth rate of gross value added in services in 2007-2011 was also negative in all sub-regions (average 84) similar to the type 3).

Type 4 - less developed sub-regions (average of GDP 20 of EU28). High employment in agriculture (117-362 per 1.000 persons of working age). The highest level of construction development. In most sub-regions (except 2) net migration is negative, in all sub-regions the population has decreased. Growth rate of employment in 20062012 average only for this type was positive (102). In most (4) sub-regions employment has been increased. Growth rate of gross value added in services in 2007-2011 was negative in all sub-regions (average 84 - similar to the type 3 ). 
Tab. 3. Quantitative characteristic of types by modified principal components

\begin{tabular}{|c|c|c|c|c|c|c|c|c|c|}
\hline Type & Cases & Measure & MC1 & MC2 & MC3 & MC4 & MC5 & MC6 & MC7 \\
\hline \multirow{3}{*}{1} & \multirow{3}{*}{19} & Maximum & 4.73 & -1.79 & 2.05 & 0.92 & 1.33 & 1.48 & 2.19 \\
\hline & & Minimum & 0.99 & -5.76 & -1.17 & -1.46 & -1.19 & -0.48 & -0.82 \\
\hline & & Standard deviation & 0.72 & 0.93 & 0.77 & 0.70 & 0.60 & 0.55 & 0.79 \\
\hline \multirow{3}{*}{2} & \multirow{3}{*}{13} & Maximum & 2.70 & -1.12 & 1.38 & 1.23 & 1.70 & 1.18 & 1.90 \\
\hline & & Minimum & -2.64 & -3.58 & -1.72 & -2.50 & -2.55 & -1.09 & -0.95 \\
\hline & & Standard deviation & 1.29 & 0.77 & 0.91 & 0.97 & 1.51 & 0.59 & 0.75 \\
\hline \multirow{3}{*}{3} & \multirow{3}{*}{14} & Maximum & 0.68 & -1.66 & -0.19 & 0.96 & 0.29 & 0.40 & -0.65 \\
\hline & & Minimum & -2.46 & -3.53 & -2.08 & -1.56 & -0.98 & -0.66 & -1.88 \\
\hline & & Standard deviation & 0.87 & 0.61 & 0.60 & 0.64 & 0.39 & 0.28 & 0.43 \\
\hline \multirow{3}{*}{4} & \multirow{3}{*}{7} & Maximum & -1.72 & -1.24 & 0.67 & 1.10 & 1.18 & 0.33 & -1.00 \\
\hline & & Minimum & -6.09 & -3.03 & -1.02 & -0.25 & -0.25 & -0.38 & -1.83 \\
\hline & & Standard deviation & 1.35 & 0.60 & 0.52 & 0.42 & 0.42 & 0.25 & 0.24 \\
\hline
\end{tabular}

MC - modified components. The smaller the standard deviation, the darker the field

Source: own elaboration based on Eurostat

Tab. 4. Quantitative characteristic of types by input variable raw values

\begin{tabular}{|c|c|c|c|c|c|c|c|c|}
\hline \multirow{2}{*}{ Variables } & \multicolumn{2}{|c|}{ Type 1} & \multicolumn{2}{|c|}{ Type 2} & \multicolumn{2}{|c|}{ Type 3} & \multicolumn{2}{|c|}{ Type 4} \\
\hline & $\min$ & $\max$ & $\min$ & $\max$ & $\min$ & $\max$ & $\min$ & $\max$ \\
\hline $\begin{array}{l}\text { Gross domestic product per capita } \\
\text { as \% of EU average }\end{array}$ & 32.0 & 71.0 & 11.0 & 48.0 & 18.0 & 35.0 & 15.0 & 26.0 \\
\hline $\begin{array}{l}\text { Gross value added \% in: } \\
\text { industry }\end{array}$ & 35.5 & 63.8 & 34.9 & 50.3 & 34.8 & 53.5 & 35.7 & 46.8 \\
\hline construction & 3.3 & 8.5 & 0.7 & 10.7 & 4.2 & 10.3 & 6.9 & 11.3 \\
\hline agriculture & 1.0 & 6.6 & 1.0 & 11.3 & 4.2 & 17.9 & 5.9 & 16.4 \\
\hline $\begin{array}{l}\text { Employees per } 1000 \text { persons } \\
\text { in working age: } \\
\text { in industry }\end{array}$ & 144.0 & 304.0 & 104.0 & 307.0 & 112.0 & 231.0 & 98.0 & 248.0 \\
\hline in agriculture & 6.0 & 176.0 & 34.0 & 231.0 & 42.0 & 194.0 & 117.0 & 362.0 \\
\hline $\begin{array}{l}\text { Gross value added per } 1000 \\
\text { persons in working age: } \\
\text { in agriculture } \\
\end{array}$ & 0.2 & 1.1 & 0.2 & 1.4 & 0.3 & 1.0 & 0.5 & 0.8 \\
\hline in industry & 11.5 & 4.2 & 7.9 & 1.8 & 5.2 & 2.2 & 3.2 & 1.7 \\
\hline Population density & 49.7 & 319.5 & 34.3 & 411.0 & 49.1 & 174.7 & 59.7 & 86.3 \\
\hline $\begin{array}{l}\text { Net migration in } 2007-2010 \text { per } \\
1000 \text { inhabitants }\end{array}$ & -2.3 & 6.9 & -10.6 & 0.3 & -5.7 & 1.4 & -3.2 & 2.2 \\
\hline $\begin{array}{l}\text { Employees per } 1000 \text { inhabitants } \\
\text { in working age }\end{array}$ & 476.0 & 784.0 & 426.0 & 736.0 & 381.0 & 605.0 & 532.0 & 708.0 \\
\hline $\begin{array}{l}\text { Growth rate of: } \\
\quad \text { - employment in } 2006-2012\end{array}$ & 84.3 & 106.3 & 71.7 & 120.0 & 83.1 & 98.1 & 94.6 & 109.5 \\
\hline - gross value added in services & 96.1 & 137.5 & 96.2 & 124.1 & 73.7 & 92.3 & 79.7 & 86.0 \\
\hline - total population & 89.5 & 101.8 & 85.8 & 103.5 & 88.0 & 97.3 & 89.0 & 96.8 \\
\hline
\end{tabular}

Source: own elaboration based on Eurostat 
Fig. 3. Types of non-metropolitan industrial NUTS 3 sub-regions in the European Union

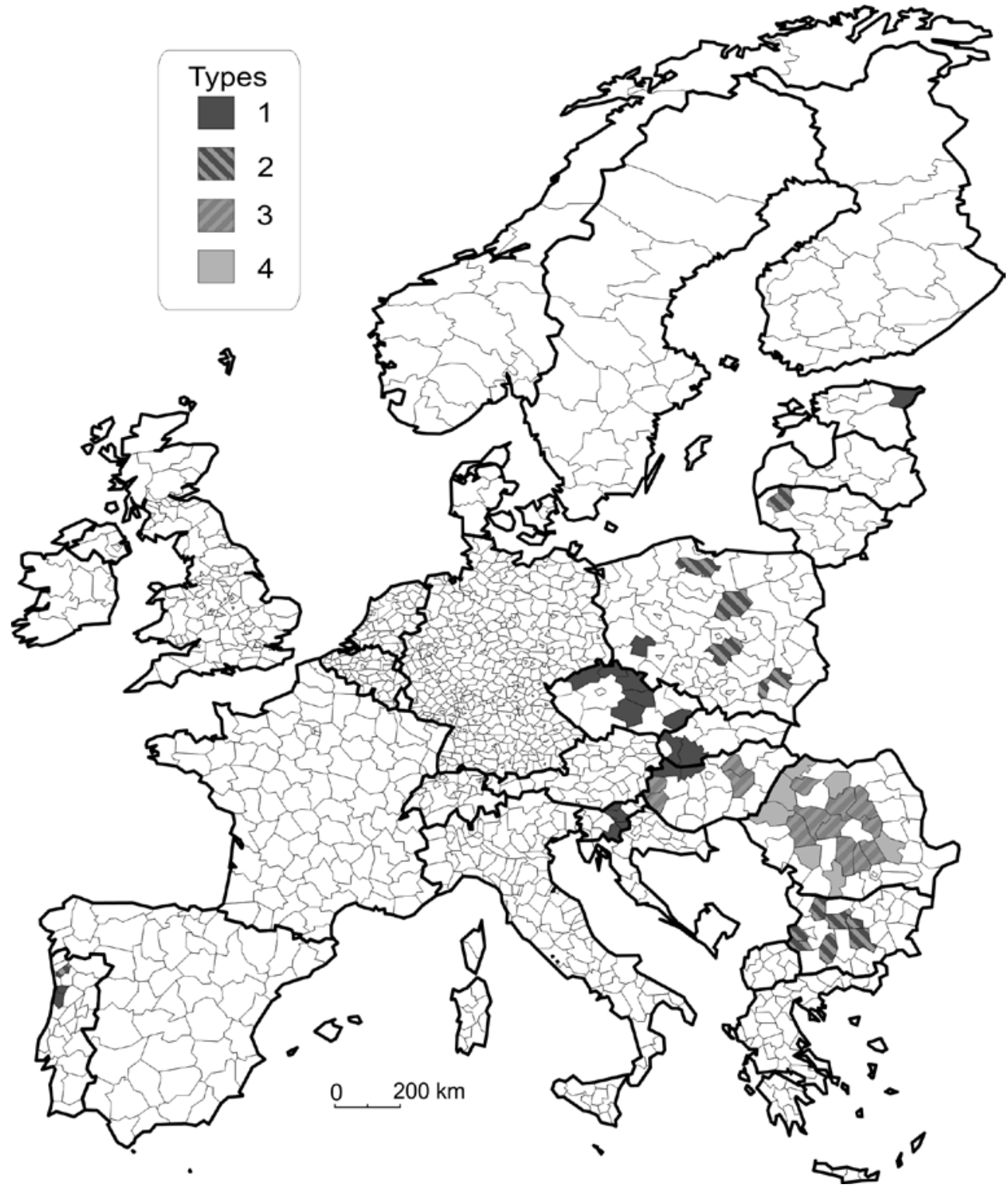

Source: own elaboration

\section{Cluster membership}

General typology result by countries is shown in Fig. 3 .

The following list organizes specific sub-regions of countries according to type.

Type 1

CZ: Ústeckýkraj, Libereckýkraj, Královéhradeckýkraj, Pardubickýkraj, Kraj Vysocina, Zlínskýkraj; 
EE: Kirde-Eesti;

HU: Komárom-Esztergom,Gyor-Moson-Sopron;

PL: Legnicko-Glogowski;

PT: Entre Douro e Vouga, Baixo Vouga;

SI: Koroska, Savinjska, Zasavska, Spodnjeposavska, Jugovzhodna Slovenija;

SK: Trnavský kraj, Nitriansky kraj.

\section{Type 2}

BG313: Vratsa, Lovech, Gabrovo, Stara Zagora, Pernik, Kyustendil, Pazardzhik;

LT008: Telsiu Apskritis;

PL115: Piotrkowski, Ciechanowsko-plocki, Tarnobrzeski, Starogardzki;

PT113: Ave.

\section{Type 3}

HU222: Vas, Zala, Heves, Jász-Nagykun-Szolnok;

R0116: Salaj, Alba, Covasna, Harghita, Mures, Sibiu, Arges, Dâmbovita, Prahova, Hunedoara, Bihor, Bistrita-Nasaud, Satu Mare, Buzau, Gorj, Olt, Arad.

\section{Type 4}

RO: Bihor, Bistrita-Nasaud, Satu Mare, Buzau, Gorj, Olt, Arad.

\section{BRANCHES OF INDUSTRY IN CHOSEN SUB-REgIONS}

To recognize a more detailed industry in sub-regions examined, information about this industry has been provided in selected sub-regions. The criterion for selection was as follows: $25-30 \%$ of the sub-regions of each type, different countries (if present in type), high share of industry in gross value added, information available by the Internet. Information was obtained for 18 sub-regions (Table 5).

Analysis of information in Table 5 shows a wide range of industry by branches and in terms of the concentration degree in branches and space. In some sub-regions there are dominant industries concentrated in one site (e.g. refinery and petrochemical plant in Płock). In other analyzed sub-regions the industry is more diversified. Greater variety of industry makes the sub-region more resistant to changes in economic situation and other circumstances.

Tab. 5. Branches of industry in chosen sub-regions

\begin{tabular}{|c|c|l|l|}
\hline Type & Country & \multicolumn{1}{|c|}{ Sub-region } & \multicolumn{1}{c|}{ Branches of industry } \\
\hline $\mathbf{1}$ & PL & $\begin{array}{l}\text { Legnicko- } \\
\text { Glogowski }\end{array}$ & Ore mining and processing of copper \\
\hline $\mathbf{1}$ & HU & $\begin{array}{l}\text { Komárom- } \\
\text { Esztergom }\end{array}$ & $\begin{array}{l}\text { Motor vehicle, manufacturing of cement, paper, plastics, } \\
\text { prefabricated building components, }\end{array}$ \\
\hline $\mathbf{1}$ & EE & Kirde-Eesti & $\begin{array}{l}\text { Shale mining and production, generation of electricity, industrial } \\
\text { parks }\end{array}$ \\
\hline $\mathbf{1}$ & PT & $\begin{array}{l}\text { Entre Douro e } \\
\text { Vouga }\end{array}$ & Light industry, manufacturing of paper, shoe \\
\hline $\mathbf{1}$ & CZ & Zlínskýkraj & Metalworking, wood-processing \\
\hline
\end{tabular}




\begin{tabular}{|c|c|c|c|}
\hline 1 & SI & Koroska & $\begin{array}{l}\text { Manufacturing of batteries, alloy steel and machinery } \\
\text { components, metal products, metal processing, component } \\
\text { manufacture for the automotive industry and mechanical } \\
\text { engineering }\end{array}$ \\
\hline 1 & PT & BaixoVouga & $\begin{array}{l}\text { Heavy industry; paper, ceramics, chemicals, automobiles, food } \\
\text { processing }\end{array}$ \\
\hline 2 & $\mathrm{BG}$ & Stara Zagora & Power production based on coal mining, industrial zone \\
\hline 2 & BG & Pazardzhik & $\begin{array}{l}\text { Hydroelectric power engineering, timber and wood processing, } \\
\text { engineering and metal processing; chemical with pulp and paper, } \\
\text { rubber, car battery and bio-medical production, ore mining and } \\
\text { processing of copper, marble, granite, sand and lime, dolomite } \\
\text { and muscovite; food processing, textile, tailoring, leather and } \\
\text { shoe industries }\end{array}$ \\
\hline 2 & PL & Piotrkowski & $\begin{array}{l}\text { Lignite mining and power plant, engineering, mechanical } \\
\text { precision-machining, paper }\end{array}$ \\
\hline 2 & PT & Ave & Textile industry, clothing and apparel \\
\hline 2 & PL & $\begin{array}{l}\text { Ciechanowsko- } \\
\text { plocki }\end{array}$ & Petrochemical, food processing \\
\hline 3 & RO & Prahova & Oil extracting, oil industry, chemical, rubber \\
\hline 3 & RO & Arges & Oil refinery,2 automobile plants \\
\hline 3 & RO & Sibiu & $\begin{array}{l}\text { Automotive components, machine components, textiles, agro- } \\
\text { industry, electrical components }\end{array}$ \\
\hline 3 & $\mathrm{HU}$ & $\begin{array}{l}\text { Jász-Nagykun- } \\
\text { Szolnok }\end{array}$ & $\begin{array}{l}\text { Food processing, electronic, electro-technical, precision } \\
\text { mechanic, machine industry and repairing, wood, metal building } \\
\text { industry }\end{array}$ \\
\hline 4 & Ro & Arad & $\begin{array}{l}\text { Railroad cars, food processing, furniture and household } \\
\text { accessories, equipment for the car industry, electric components, } \\
\text { instrumentation, clothing, textiles, footwear, distilling, milling, } \\
\text { machinery-making, leather-working, saw-milling }\end{array}$ \\
\hline 4 & Ro & Satu Mare & $\begin{array}{l}\text { Automotive (electric engine components, wiring), kitchen stove, } \\
\text { steel tubes; Industrial Park }\end{array}$ \\
\hline
\end{tabular}

Source: Zimin (2014), http://www.ecreinplus.malopolska.pl, http://www.icicom.hu/teruletfo/csmeng16.htm, http://www.investbulgaria.com/Pazardjik.php, http://www.rra-koroska.si/en/koroska

\section{CONCLUSIONS}

There are more than 300 non-metropolitan NUTS 3 sub-regions in European Union in which gross domestic product per capita in 2011 was below $75 \%$ of the EU average. In 53 of these sub-regions rate of gross value added in industry is above $35 \%$ (maximum is 64\%). They may be called industrial. Almost all of them belong to 9 post-socialist countries, three - to Portugal. It means that in other sub-regions services are better developed.

Sub-regions examined are various. In most of them GDP per capita in 2011 was below $30 \%$ of the EU average. Low developed services can be regarded as the cause of the low level of GDP and the high rate of gross value added in industry. In the type of the lowest developed regions the growth rate of gross value added in services in 
2007-2011 was negative, which means that the situation is becoming worse. The industry analyzed in $30 \%$ sub-regions also proved to be diversified. Some industries may create an opportunity to develop if they are modern and competitive. But a better opportunity of development should be seen in the development of services.

The concept for taking into account the eigenvalues of principal component in clustering sub-regions has been verified partly positively. The first component has played the biggest role in the clustering (but only the first one). The weaknesses of typology has appeared which differs typology from classification: large range of values of components and variables in one type and similar values in more than one type. From those reasons types have been characterized by several or all components at once (not by single components), and by all measures at once (average, maximum and minimum) and even by more detailed characteristics of specific values. It has resulted in difficulties in interpretation of types. It can be supposed that a large number of variables, low correlated, has an impact on the results of the typology and the interpretational difficulties.

Directions for further research can be as follows:

- searching for an appropriate set of variables in situation, when there is a large number of variables and when there is too little data;

- testing methods (including making decision on the number of types) by doing typologies and classification in a larger set of sub-regions, especially for all non-metro sub-region in EU;

- preparing typologies of sub-region with high developed industry.

Statistical characteristics of sub-regions is obviously not enough to assess the opportunities of sub-regions on the development and the role of industry in this process. It is also necessary to take into account the individual characteristics of the industry in sub-regions in terms of the stability, competitiveness of products, diversity and the degree of spatial concentration and also other important features of sub-regions.

\section{References}

Abdi, H., Williams, L.J. (2010). Principal component analysis. Wiley Interdisciplinary Reviews: Computational Statistics, 4, 433-459.

ACE Rev. 2, Statistical Classification of Economic Activities in the European Community (2008). Eurostat: Methodologies and Working papers, Luxembourg: Office for Official Publications of the European Communities. Retrieved from http://ec.europa.eu/eurostat/documents/3859598/5902521/KSRA-07-015-EN.PDF

Banning E.B., (2000). Classification, grouping, typology. In: ARH 312Y - Archaeological Laboratory, Systematics. Retrived from http://homes.chass.utoronto.ca/ banning/ARH\%20312/312Ysyst.htm

Bauer, R. (2010). Scaling through Space: A Demographic Typology of European Regions, Department of Geography \& Regional Research University of Vienna. Retrieved from http://www.oeaw.ac.at/vid/ download/col101214rb.pdf

Chojnicki Z., Czyż T. (1978). Podstawy metodologiczne zastosowania analizy czynnikowej. In: Z. Chojnicki, T. Czyż, J. Parysek, W. Ratajczak (ed.), Badanie przestrzennej struktury społeczno-ekonomicznej Polski metodami czynnikowymi. Geografia 2. Poznań-Warszawa: PWN, 7-20.

Development of a regional typology - Aim, methods and results. Work package 6 - Typology of regions in Europe November (2010) I2SARE. Retrieved from http://www.i2sare.eu.

Domański, B. (2008). Rozwój polskich metropolii a regiony peryferyjne. Bezpowrotna separacja czy współzależność rozwoju?, Studia KPZK PAN, 120, 135-143. 
Domański, R. (2005). Geografia ekonomiczna. Ujęcie dynamiczne. Warszawa: Wydawnictwo Naukowe PWN.

Dorocki, S. (2008). Kształtowanie się regionów przemysłowych Francji. Prace Komisji Geografii Przemysłu Polskiego Towarzystwa Geograficznego, 10, 45-54.

Dorocki, S. (2010). Gospodarka regionów granicznych w procesie integracji europejskiej. Przedsiębiorczość Edukacja, 6, 252-270.

Dorocki, S. (2012). Regional Differentiation in the Development of French Towns - Quantitative Analysis. Barometr Regionalny, 3(29), 13-31.

Eurostat: Official webpage of European Union Statistics (2014, 17-21 June). Retrieved from http://epp.eurostat.ec.europa.eu/portal/page/portal/statistics/search_database

Everitt, B.S., Landau, S., Leese, M., Stahl, D. (2011). Cluster Analysis. Chichester: Wiley.

Gałązka, A. (2011). Czynniki rozwoju w wybranych teoriach rozwoju regionalnego. In: Z. Strzelecki (ed.), Gospodarka regionalna $i$ lokalna $w$ Polsce, Warszawa: Oficyna Wydawnicza Szkoła Handlowa w Warszawie.

Gorzelak G. (1979). Dobór zmiennych w statystycznej analizie porównawczej - metody (I). Wiadomości Statystyczne, 3, 17-21.

Jackson, J.E. (1991). A User's Guide To Principal Component. New York: John Wiley \& Sons.

Lolliffe, I.T. (2002). Principal Component Analysis. New York: Springer.

Maćkiewicz A., Ratajczak W. (1993). Principal components analysis (PCA). Computers\&amp;Geosciences, 19, (3), 303-342. DOI:10.1016/0098-3004(93)90090- R

Morrison D.F. (1967). Multivariate statistical methods. New York: McGrawHill.

Nowak E. (2012). Główne składowe zróżnicowania regionalnego ze względu na popyt i podaż turystyczną oraz rozwój społeczny : podejście klasyfikacyjne. Nierówności Społeczne a Wzrost Gospodarczy, 28, 274-286.

Parysek J., Ratajczak W. (2002). Analiza składowych głównych, jej korzyści i ograniczenia zpunktu widzenia badań geograficznych. In: H. Rogacki (ed.), Możliwości iograniczenia zastosowania metod badawczych w geografii i gospodarceprzestrzennej. Poznań: Bogucki Wyd. Nauk., 61-73.

Shepherd, J. (2009) (2013, 20 May). Typology of the Smaller Rural Sub-regions of England, Rural Evidence Research Centre Birkbeck College. Retrived from www.rerc.ac.uk

Sołtys, J. (2014). Typology of peripheral sub-regions in the European Union. 54th Congress of the European Regional Science Association: "Regional development \& globalisation: Best practices", 26-29 August 2014, St. Petersburg.

Sołtys, J. (2015). Typology of low developed non-metropolitan sub-regions in the European Union, Prace Naukowe Uniwersytetu Ekonomicznego we Wrocławiu, 394, 153-165.

Typology of metro regions (2012) (2015, 23 June). Retrived from epp.eurostat.ec.europa.eu/portal/page/ portal/region_cities/metropolitan_regions

Zimin, D. (2014). Kirde-Eesti, Estonia: Patterns of Socio-Economic Development-Case Study Report, Grincoh Working Paper Series Paper No 6.03.03.02.

Jacek Sołtys, Graduated from Gdansk University of Technology, Faculty of Architecture. Teaching duties (courses taught): regional planning (since 1975-2014), local planning, strategic planning, designing of tourist and recreational areas development. Research interests: methods of planning (spatial, strategic, including scenario method), sustainable development, typology of towns and regions, settlement network, regional development of non-metropolitan areas. He was worked in numerous international and national research projects. Author of two books and more than 40 other publications. Co-author of more than 30 strategies for municipalities. Member of the European Regional Science Association and the Society of Polish Town Planners. Tourist guide.

\section{Address:}

Politechnika Gdańska

Wydział Architektury

Katedra Urbanistyki i Planowania Regionalnego

ul. Gabriela Narutowicza 11/12, Polska

e-mail: jacek.soltys@gmail.com 
Sławomir Dorocki, graduated from the Pedagogical University in Krakow - M.Sc. degree in geography, Ph.D. in history (Institute of European Studies of the Jagiellonian University). Adiunkt (assoc. professor) at the Pedagogical University of Cracow, Institute of Geography. His research interests are tied with regional problems and processes of socio-economic regionalization, with particular emphasis on the diversity of Europe, processes of European integration and historical conditions.

\section{Address:}

Uniwersytet Pedagogiczny w Krakowie Instytut Geografii

Zakład Przedsiębiorczości i Gospodarki Przestrzennej

ul. Podchorążych 2, 30-084 Kraków, Polska

e-mail:sdorocki@up.krakow.pl 